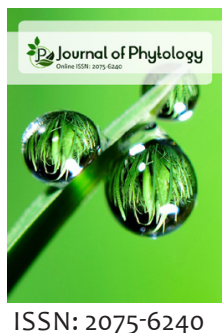

ISSN: $2075-6240$

Received: June 02, 2020 Revised: June 28, 2020 Accepted: July 01, 2020 Published: July 10, 2020

*Corresponding author: Panagiotis Kanatas Email: pakanatas@gmail.com

\section{Seed priming effects on germination and first growth of the medicinal plant Achillea millefolium L.}

\author{
Panagiotis Kanatas ${ }^{1^{*}}$, Vyronas Dellaportas ${ }^{2}$, loanna Kakabouki ${ }^{2}$ and \\ Panayiota Papastylianou ${ }^{2}$
}

${ }^{1}$ Agricultural Cooperative of Mesolonghi-Nafpaktia, 30200 Mesolonghi, Greece; 'Department of Crop Science, Agricultural University of Athens, 75, lera Odos str., 11855 Athens, Greece

\begin{abstract}
This study evaluated the effects of seed priming on germination and growth of A. millefolium by means of laboratory and greenhouse experiments conducted during 2018 in Agricultural University of Athens. Treatments were GA 3 ( 400 and $800 \mathrm{ppm}$ ), potassium nitrate (2\% and 4\%), polyethylene-glycol (soaking for 12 and $24 \mathrm{~h}$ ) besides an untreated control. Experiment in Petri dishes revealed that $\mathrm{GA}_{3}$ at $400 \mathrm{ppm}$, potassium nitrate (at concentration 2 and $4 \%$ ) and PEG significantly increased germination percentage of A. millefolium, while germination rate was also significantly improved as a result of all seed priming techniques. In addition, due to the soil experiment, seedling emergence was significantly increased by $\mathrm{GA}_{3}$ at $400 \mathrm{ppm}$, potassium nitrate (at both concentrations) and PEG compared with the untreated seeds. Dry biomass of the young seedlings was significantly enhanced by means of $\mathrm{GA}_{3}$ (at 400 and $800 \mathrm{ppm}$ ), $\mathrm{KNO}_{3}(4 \%)$ and PEG for $24 \mathrm{~h}$, indicating the potential effect of seed priming on first growth as well. The results of the present study revealed the significant positive effects of seed priming on A. millefolium seed germination, seedling emergence and early growth.
\end{abstract}

KEYWORDS: Medicinal plants, seed priming, Achillea millefolium, seed germination

\section{INTRODUCTION}

New health challenges along with the observed reduction of efficacy and the increase of toxicity or side-effects of synthetic drugs increase the interest in herbal drugs and medicinal plants [1]. Medicinal plants are widely used for the production of drugs, food supplements, cosmetics and other products and therefore the interest is high, even there are significant differences on the rules and procedures between the countries of the European Union [2].

Achillea millefolium (yarrow) is a medicinal plant known since ancient years and a member of Asteraceae family. Its use was continuous and widespread, with reports that the seventh century AD the Slavic people used A. millefolium against several insects [3]. It is a plant used against dyspepsia, colic, diarrhea, hypertension, rheumatisms and for the treatment of many ailments due to the inflammatory antioxidant properties of the secondary metabolites [4,5]. Petrakou et al. (2020) found that A. millefolium was one of the medicinal plants with the highest relative importance and high use, in a large region of Greece and other Mediterranean countries [6].
Many medicinal plants have problems in seed germination and field performance and consequently, suggesting seed quality enhancement methods is necessary [7]. Seed priming is one of the methods of seed treatment for quality improvement and seed enhancement in different crops and can be defined as the process of controlled hydration of seeds [8,9]. In many cases, seed priming enhances rapid and uniform germination and seedling vigor in several crops and under a wide range of soil and climatic conditions $[10,11]$. There are several priming techniques used for seeds such as chemopriming, thermopriming, hydropriming and osmopriming [10,12]. Polyethylene glycol (PEG), gibberellins (GA) and potassium nitrate $\left(\mathrm{KNO}_{3}\right)$ are well documented chemicals which increase the seed germination of several plant species $[13,14]$.

Low seed germination and a considerable variation between seed batches of A. millefolium have been reported $[15,16]$. Therefore, the objective of this research was to determine the effects of different seed priming treatments on seed germination parameters and seedling emergence and early growth of the medicinal plant, A. millefolium.

Copyright: $\odot$ The authors. This article is open access and licensed under the terms of the Creative Commons Attribution License (http://creativecommons.org/licenses/by/4.0/) which permits unrestricted, use, distribution and reproduction in any medium, or format for any purpose, even commercially provided the work is properly cited. Attribution - You must give appropriate credit, provide a link to the license, and indicate if changes were made. 


\section{MATERIALS AND METHODS}

This study examined the effects of seed priming on germination and growth of A. millefolium by means of laboratory and greenhouse experiments conducted during 2018 (April to June) in Agricultural University of Athens. Seeds were collected by an experimental field in western Greece and properly stored until the establishment of the present experiments. Before the beginning of the experiment, the seeds were disinfected with $5 \%$ sodium hypochlorite solution for 2 min. After that, seeds were washed with distilled water and 25 of them were put in Petri dishes on sterilized Whatman papers. Seed priming treatments were gibberellic acid $\left(\mathrm{GA}_{3}\right)$ with dosages of 400 and $800 \mathrm{ppm}$, potassium nitrate (2\% and $4 \%$ ), polyethylene-glycol (PEG) 6000 for 12 and 24h and control (untreated). The selection of the specific concentrations was based on previous preliminary tests. $5 \mathrm{ml}$ of water was added to each dish and there were 4 dishes for each treatment and the untreated control. Germination experiments lasted 16 days and they were carried out in a completed randomized design under laboratory conditions, in growth chambers (Conviron $\mathrm{T}$ $38 / \mathrm{Lb} / \mathrm{AP})$ at constant temperature $\left(25^{\circ} \mathrm{C}\right)$ and total darkness. Seeds were considered germinated at the emergence of the radicle [17].

After the lapse of the experimental period (16 days), germination percentage and rate of germination were evaluated. Germination rate (GR) was determined using Maguire's index [18] as follows:

GR $=$ (Number of germinated seeds at first count / day of first count $)+($ Number of germinated seeds at second count / day of second count $)+\ldots+$ (Number of germinated seeds at last count / day of last count).

Subsequently, the emergence of the seedlings (as a percentage of the seeds) was also recorded in a cell tray experiment in a glasshouse. Minimum/maximum air temperature and relative humidity were: $22 / 38^{\circ} \mathrm{C}$ and $36 / 54 \%$, respectively and the seeds and seedlings were subjected to a natural day length ranging between 12 and $14 \mathrm{~h}$ during the experiment. The seeds were primed with $\mathrm{GA}_{3}, \mathrm{KNO}_{3}$ and PEG as previously described and seeds were sown and covered with soil in cell trays (20 cells for each treatment). It was used a slightly calcareous sandy clay loam (SCL) soil $(\mathrm{pH}=7.1)$. Cell dimensions were $13 / 4 "$ x 13/4" and seed tray outer dimensions were $21 \frac{1 / 4}{4} \times 11^{1 / 4}$ " x 21/4". The plants were irrigated with equal amount of water $(5 \mathrm{ml}$ in each cell) every day and seedling emergence was determined. After 30 days, seedlings were cut in the soil surface, their length was measured and the dry weight was also recorded after oven drying at $60{ }^{\circ} \mathrm{C}$ for $24 \mathrm{~h}$.

The percentages of germination and emergence (after arcsine transformation) were subjected to one-way analysis of variance (ANOVA) using the Statgraphics statistical software package (v.5.0, Statistical Graphics Corporation, Englewood Cliffs, NJ, USA). Mean comparison was performed using Fisher's least significant difference (LSD) method $(\mathrm{P}=0.05)$.

\section{RESULTS}

The effects of the several seed priming treatments on germination percentage and germination rate are presented in Table 1. $\mathrm{GA}_{3}$ at $400 \mathrm{ppm}$, potassium nitrate (at both concentrations) and PEG significantly increased germination percentage of A. millefolium. Germination rate was also significantly increased as a result of all seed priming techniques.

In Table 2, the effects of seed priming on seedling emergence percentage and germination rate of A. millefolium is shown. Seedling emergence was significantly increased by $\mathrm{GA}_{3}$ at 400 ppm, potassium nitrate (at both concentrations) and PEG compared with the untreated seeds. Germination rate was also positively and significantly affected by the same seed treatments, while the effect of $\mathrm{GA}_{3}$ at $800 \mathrm{ppm}$ and $\mathrm{KNO}_{3}(2 \%)$ was no significant $(\mathrm{p}>0.05)$.

Greenhouse experiments also revealed significant differences in the shoot length and dry weight of A. millefolium plants between the several treatments (Table 3). In particular, GA treatments resulted in the highest plants. In addition, dry biomass was significantly enhanced by means of GA3 (at 400 and 800 ppm), $\mathrm{KNO}_{3}(4 \%)$ and PEG for $24 \mathrm{~h}$.

\section{DISCUSSION}

The present study was aimed at determining the potential effects of several seed priming methods on seed germination and seedling emergence and growth parameters of A. millefolium.

Table 1: Germination percentage and germination rate of A. millefolium in response to several seed priming treatments (experiment in Petri dishes). Means within a column followed by the same letter are not significantly different according to Fischer's least significant difference test at a $\mathrm{P}=0.05$ level

\begin{tabular}{lcc}
\hline & Germination percentage (\%) & Germination rate \\
\hline Untreated & $58 \pm 2.6^{\mathrm{a}}$ & $22 \pm 0.4^{\mathrm{a}}$ \\
$\mathrm{GA}_{3} 400 \mathrm{ppm}$ & $67 \pm 0.3^{\mathrm{b}}$ & $29 \pm 0.8^{\mathrm{b}}$ \\
$\mathrm{GA}_{3} 800 \mathrm{ppm}$ & $57 \pm 1.8^{\mathrm{a}}$ & $27 \pm 0.6^{\mathrm{b}}$ \\
$\mathrm{KNO}_{3}(2 \%)$ & $64 \pm 2.2^{\mathrm{a}, \mathrm{b}}$ & $29 \pm 0.5^{\mathrm{b}}$ \\
$\mathrm{KNO}_{3}(4 \%)$ & $71 \pm 1.7^{\mathrm{b}, \mathrm{c}}$ & $32 \pm 0.4^{\mathrm{b}}$ \\
$\mathrm{PEG}(12 \mathrm{~h})$ & $77 \pm 2.8^{\mathrm{c}, \mathrm{d}}$ & $38 \pm 0.9^{c}$ \\
$\mathrm{PEG}(24 \mathrm{~h})$ & $84 \pm 2.6^{\mathrm{d}}$ & $36 \pm 0.5^{\mathrm{c}}$ \\
\hline
\end{tabular}

Table 2: Seedling emergence percentage and germination rate of $A$. millefolium in response to several seed priming treatments (experiment in soil). Means within a column followed by the same letter are not significantly different according to Fischer's least significant difference test at a $\mathrm{P}=0.05$ level

\begin{tabular}{lcc}
\hline & Seedling emergence (\%) & Germination rate \\
\hline Untreated & $55 \pm 1.1^{\mathrm{a}}$ & $23 \pm 0.3^{\mathrm{a}}$ \\
$\mathrm{GA}_{3} 400 \mathrm{ppm}$ & $63 \pm 0.5^{\mathrm{b}}$ & $31 \pm 0.4^{\mathrm{b}}$ \\
$\mathrm{GA}_{3} 800 \mathrm{ppm}$ & $56 \pm 1.2^{\mathrm{a}}$ & $25 \pm 0.5^{\mathrm{a}}$ \\
$\mathrm{KNO}_{3}(2 \%)$ & $61 \pm 1.3^{\mathrm{a}, \mathrm{b}}$ & $28 \pm 0.4^{\mathrm{a}, \mathrm{b}}$ \\
$\mathrm{KNO}(4 \%)$ & $67 \pm 1.2^{\mathrm{b}}$ & $30 \pm 1.3^{\mathrm{b}}$ \\
$\mathrm{PEG}(12 \mathrm{~h})$ & $74 \pm 2.1^{\mathrm{c}}$ & $33 \pm 0.6^{\mathrm{b}, \mathrm{c}}$ \\
$\mathrm{PEG}(24 \mathrm{~h})$ & $78 \pm 1.7^{\mathrm{c}}$ & $35 \pm 1.5^{\mathrm{c}}$ \\
\hline
\end{tabular}


Table 3: Shoot length and above-ground dry weight of A. millefolium seedlings in response to several seed priming treatments (experiment in soil). Means within a column followed by the same letter are not significantly different according to Fischer's least significant difference test at a $\mathrm{P}=0.05$ level

\begin{tabular}{lcc}
\hline & Shoot length (cm) & Above-ground dry weight $(\mathrm{g})$ \\
\hline Untreated & $16.1 \pm 1.6^{\mathrm{a}}$ & $4.3 \pm 0.3^{\mathrm{a}}$ \\
$\mathrm{GA}_{3} 400 \mathrm{ppm}$ & $22.2 \pm 1.9^{\mathrm{c}}$ & $5.1 \pm 0.7^{\mathrm{b}, \mathrm{c}}$ \\
$\mathrm{GA}_{3} 800 \mathrm{ppm}$ & $23.3 \pm 2.3^{\mathrm{c}}$ & $5.3 \pm 0.8^{\mathrm{c}}$ \\
$\mathrm{KNO}_{3}(2 \%)$ & $16.6 \pm 0.9^{\mathrm{a}}$ & $4.4 \pm 0.6^{\mathrm{a}}$ \\
$\mathrm{KNO}_{3}(4 \%)$ & $17.2 \pm 1.6^{\mathrm{a}, \mathrm{b}}$ & $5.1 \pm 0.6^{\mathrm{b}, \mathrm{c}}$ \\
$\mathrm{PEG}(12 \mathrm{~h})$ & $19.4 \pm 0.9^{\mathrm{b}}$ & $4.5 \pm 0.3^{\mathrm{a}}$ \\
$\mathrm{PEG}(24 \mathrm{~h})$ & $17.2 \pm 1.3^{\mathrm{a}, \mathrm{b}}$ & $4.9 \pm 0.4^{\mathrm{b}}$ \\
\hline
\end{tabular}

Our results on seed germination are in accordance with Mirshekari et al. (2013), who found that germination percentage of untreated A. millefolium seeds was not higher than 70\% [16]. Fetri et al. (2014) studied the effects of salinity and drought on A. millefolium germination and seedling growth and revealed that drought and salinity stresses reduced significantly germination rate, germination percentage and shoot length [19].

Due to the low and variable seed germination, any practices that may enhance germination and emergence of A. millefolium are urgently needed [15]. Seed quality enhancement techniques improve seed germination of medicinal and aromatic crops. Hoseini et al. (2013) reported that seed priming treatments in two varieties of lemon balm increase antioxidant enzymes and germination percentage [20]. Several seed priming techniques have been used on A. millefolium, with positive effects in the majority of them [16]. Sedghi et al. (2010) reported that seed priming had significant effect on germination percentage, germination speed, root and shoot length in two medical plants (marigold and sweet fennel) [21].

In the present study, seed priming through the use of gibberellic acid at $400 \mathrm{ppm}$ had a positive effect on seed germination and germination rate and this finding is in full agreement with the findings of previous studies, revealing the effects of gibberellic acid on the seed germination of different species [22]. In addition, the improvement of seed emergence and growth characteristics of A. millefolium by means of $\mathrm{GA}_{3}$ has been previously reported in other medicinal species like Anthemis pseudocotula [23]. Similarly, in Calendula officinalis, Ganji Arjenaki et al. (2011) observed that osmo-priming with PEG-6000 enhanced germination percentage, germination rate and radicle and shoot lengths [24]. Furthermore, Fariman et al. (2011) also found that seed priming improved germination percentage and speed of germination in Echinacea purpurea [25]. Regarding potassium nitrate and its effect on emergence and initial seedling establishment, Tzortzakis (2009) revealed that there were positive effects on weight of Cichorium spp. seedlings [26]. This is in agreement with our results and the results of another study on Borago officinalis, indicating the importance of seed priming for seed germination and field performance [27].

\section{CONCLUSIONS}

The benefits of different seed priming techniques in A. millefolium include higher and faster seed germination and seedling emergence and highest early growth and biomass production. In particular, $\mathrm{GA}_{3}$ at $400 \mathrm{ppm}$, potassium nitrate (at both concentrations) and PEG significantly increased germination percentage of A. millefolium, while germination rate was also significantly increased as a result of all seed priming techniques. Seedling emergence was significantly increased by $\mathrm{GA}_{3}$ at $400 \mathrm{ppm}$, potassium nitrate (at both concentrations) and PEG compared with the untreated seeds. Dry biomass of the young seedlings was significantly enhanced by means of $\mathrm{GA}_{3}$ (at 400 and $800 \mathrm{ppm}), \mathrm{KNO}_{3}(4 \%)$ and PEG for $24 \mathrm{~h}$, indicating the potential effect of seed priming on first growth as well.

\section{AUTHOR'S CONTRIBUTORS}

All the authors contributed equally in the paper. PK, VD and IK have carried out the experiments and interpreted the data. PK and PP have designed the experiment and validated the manuscript. Similarly, PK and PP wrote the manuscript.

\section{REFERENCES}

1. Anand U, Jacobo-Herrera N, Altemimi A, Lakhssassi N. A comprehensive review on medicinal plants as antimicrobial therapeutics: potential avenues of biocompatible drug discovery. Metabolites, 2019; 9:258.

2. Biagi M, Pecorari R, Appendino G, Miraldi E, Magnano AR, Governa P, Cettolin G, Giachetti D. Herbal products in Italy: the thin line between phytotherapy, nutrition and parapharmaceuticals; a normative overview of the fastest growing market in Europe. Pharmaceuticals (Basel). 2016; 9(4).

3. Bojadzievski P. The health services in Bitola through the centuries. Bitola: Society of science and art; 1992. pp. 15-27.

4. Hanlidou E, Karousou R, Kleftoyianni V, Kokkini S. The herbal market of Thessaloniki ( $N$ Greece) and its relation to the ethnobotanical tradition. Journal of Ethnopharmacology. 2004; 91:281-299.

5. Ali SI, Gopalakrishnan B, Venkatesalu V. 2017. Pharmacognosy, phytochemistry and pharmacological properties of Achillea millefolium L.: a review. Phytotherapy Research. 2017; 31(8):1140-1161.

6. Petrakou K, latrou G, Lamari FN. Ethnopharmacological survey of medicinal plants traded in herbal markets in the Peloponnisos, Greece. Journal of Herbal Medicine. 2020; 19:100305.

7. Khidrapure G, Lakshmana D, Hanumanthappa M, Rekha B, Chandana BC. Seed quality enhancement techniques in medicinal and aromatic crops: a review. Journal of Pharmacognosy and Phytochemistry. 2018; SP3:59-64.

8. Anilkumar L, Malarkodi K. Combined seed enhancement techniques involving seed priming and coating for improvised anatomical potential and vigour of okra (Abelmoschus esculentus L.) seeds. Journal of Phytology. 2019; 11:25-30.

9. Arunkumar K, Jegadeeswari V, Ushamalini C. Seed priming technology in spice crops: A review. Journal of Phytology. 2019; 11:21-24.

10. Ashraf M, Foolad MR. Pre-sowing seed treatment-a shotgun approach to improve germination growth and crop yield under saline and nonesaline conditions. Advances in Agronomy. 2005; 88:223-271.

11. Harris D, Pathan AK, Gothkar P, Joshi A, Chivasa W, Nyamudeza P. Onfarm seed priming: Using participatory methods to revive and refine a keytechnology. Agricultural Systems2001; 69:151-164.

12. Paparella S, Araújo SS, Rossi G, Wijayasinghe M, Carbonera D, Balestrazzi A. Seed priming: State of the art and new perspectives. Plant Cell Reports. 2015; 34:1281-1293.

13. Arteca RN. Plant growth substances principles and applications Chapter 3: chemistry, biological effects and mechanism of action. 
Chapman and Hall, New York, 1996; p. 66

14. Shanmugavalli M, Renganayaki PR, Menaka C. Seed dormancy and germination improvement treatments in fodder sorghum. SAT eJournal. 2007; 3:1-3.

15. Kannangara HW, Field RJ. Environmental and physiological factors affecting the fate of seeds of yarrow (Achillea millefolium L.). Weed Research. 1985; 25:87-92.

16. Mirshekari B, Farahvash F, Siyami R, Moghbeli AH, Khiabani AS. Ultrasonic irradiation could increase germination and seedling vigor of common yarrow (Achillea millefolium), as a medicinal plant. Life Science Journal. 2013; 10(5s).

17. Bewley JD, Black M. Physiology of Development and Germination. Plenum Press London, 1994; 445 p.

18. Maguire JD. Speed of germination-aid in selection and evaluation for seedling emergence and vigor. Crop Science. 1962: 2:176-177.

19. Fetri M, Dargahikhoo A, Rajabi M. Effect of drought and salinity tensions on germination and seedling growth of Common Yarrow (Achillea millefolium L.) in laboratory conditions. International Journal of Advanced Biological and Biomedical Research. 2014; 2:383-391.

20. Hoseini M, Rahimzadeh-Khoei F, Mirshekari B. Seed priming techniques improve germination and yield in two landraces of lemon balm in laboratory experiment and field study. International Journal of Indigenous Medicinal Plants. 2013; 29:1144-1150.

21. Sedghi M, Nemati A, Esmaielpour B. Effect of seed priming on germination and seedling growth of two medicinal plants under salinity. Emirates Journal of Food and Agriculture. 2010; 22(2):130-139.

22. Chauhan JS, Tomar YK, Badoni A, Indrakumar N, Seema S, Debarat A. Morphology, germination and early seedling growth in Phaseolus mungo L. with reference to the influence of various plant growth substances Journal of American Science. 2010; 6(1):34-41.

23. Sajjadi Jaghargh SS, Alizadeh MA, Kalagari M. Assessment of seed emergence characteristics and seedlings vigor of three populations aromatic medicinal plant species of Anthemis pseudocotula Boiss by using of priming technique and pre-chilling. Bulletin of Environment Pharmacology and Life Sciences. 2013; 3(1): 143-150.

24. Ganji-Arjenaki F, Amini-Dehghani M, Jabbari R. Effects of priming on seed germination of marigold (Calendula officinalis). Advances in Environmental Biology. 2011; 5:276-280.

25. Fariman ZK, Azizi M, Noori S. Seed germination and dormancy breaking techniques for Echinacea purpurea L. Journal of Biological and Environmental Sciences. 2011; 5:7-10.

26. Tzortzakis NG. Effect of pre-sowing treatment on seed germination and seedling vigour in endive and chicory. Horticultural Science. 2009: 36:117-125

27. Ghassemi-Golezani K, Dastborhan S, Zehtab-Salmasi S. Seed priming and field performance of Borage (Borago officinalis L.) under different irrigation treatments. International Journal of Agronomy and Plant Production. 2013: 4:82-87. 